\title{
Comparação entre técnica de castração cirúrgica e Burdizzo no ganho de peso de bovinos em sistema extensivo
}

Marta Valéria Rangel da Matta ${ }^{[]^{0}}$, Rodrigo César Medeiros da Silva ${ }^{[b]}$, Fabiana Batalha Knackfuss[ ${ }^{[a]}$, Yasmin Gonçalves Pereira ${ }^{[c]}$, Marcelo Alves Herdy ${ }^{[a]}$

\footnotetext{
[a] Universidade do Grande Rio (UNIGRANRIO), Duque de Caxias, RJ, Brasil

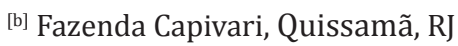

${ }^{[c]}$ Jotagro Alimentos, Itaocara, RJ, Brasil
}

*Autor correspondente

e-mail: marta.rangel@hotmail.com

\section{Resumo}

A castração de machos é prática rotineira em fazendas que criam bovinos de corte, sendo realizada com o intuito de facilitar o manejo dos animais e produzir carcaças de melhor qualidade e aceitação no mercado. Com relação aos métodos utilizados, existem discussões sobre qual o mais eficiente com relação a técnica em si, pós-operatório e a qualidade do produto final, a carne. Entretanto, o que se observa é que alguns produtores já estão abatendo seus animais sem castrar, terminados em confinamento, com carcaças de qualidade satisfatória. Atualmente, a maior restrição ao abate de bovinos machos não castrados vem dos frigoríficos, que afirmam que animais inteiros não depositam gordura como machos castrados, sendo a cobertura de gordura uma importante característica para elevar a qualidade e a consequente remuneração da carcaça. $\mathrm{O}$ objetivo deste trabalho foi avaliar as técnicas de castração cirúrgica (T1) e mecânica Burdizzo (T2) com o grupo controle (GC), que correspondia aos animais não castrados, com relação ao ganho de peso médio após 71 dias de castração. 0 estudo foi realizado na fazenda Capivari, localizada no município de Quissamã, na região norte fluminense do Estado do Rio de Janeiro, sendo castrados pelo método cirúrgico 55 machos da raça Nelore, 53 pelo método de Burdizzo e 20 animais não foram castrados (pertencentes ao grupo controle). Os animais apresentavam idade aproximada de 24 meses e foram submetidos ao mesmo manejo antes e após o processo de castração, sendo mantidos em pastejo de Brachiaria brizantha, Brachiaria marandu e Brachiaria humidicola e recebendo a mesma suplementação. Para a realização da castração, os animais foram contidos em tronco de contenção individual e, logo após o procedimento, foram pesados individualmente em balança mecânica. A segunda pesagem dos animais foi realizada 36 dias após a castração e a terceira e última pesagem foi realizada aos 71 dias após a castração. As médias e os respectivos 
desvio-padrão para o ganho de peso foram para $406 \pm 34 \mathrm{~kg}$ (T1), $422 \pm 36 \mathrm{~kg}$ (T2) e $431 \pm 40 \mathrm{~kg}$ (T3). Pelo teste de Tukey não foram observadas diferenças estatísticas significativas $(p>0,05)$ entre as duas técnicas de castração (T1 e T2), entretanto, foi verificada diferença significativa entre T1 e o controle GC (p < 0,05$)$, demonstrando que as maiores médias foram dos animais inteiros. Este resultado pode ser explicado pelo fato destes animais apresentarem maior velocidade de ganho de peso e serem mais eficientes na transformação dos alimentos oferecidos em peso vivo. Quando as carcaças de bovinos inteiros e castrados são comparadas, os resultados demonstram que aquelas dos inteiros são superiores em peso e conformação, assim como apresentam maior proporção de músculo. Estas vantagens, entretanto, perdem valor comercial pela qualidade da carcaça, em função principalmente de deficiência na gordura de cobertura. Assim sendo, no mercado brasileiro existe espaço para a utilização de sistemas de produção de carne baseados no abate de animais inteiros, já que grande parte dos consumidores prefere cortes cárneos com pequena deposição de gordura. Estes sistemas, entretanto, estariam condicionados a abater os animais entre 18 e 24 meses com carcaças que apresentem um acabamento mínimo de gordura de cobertura. 